\title{
BRAČNA ZAJEDNICA U UVJETIMA KAPITALISTIČKE KOMODIFIKACIJE I IDEOLOGIJE KONZUMERIZMA
}

\author{
Hajrudin Hromadžić i Katarina Damčević
}

Filozofski fakultet Sveučilišta u Rijeci
Odsjek za kulturalne studije
Sveučilišna avenija 4, 51000 Rijeka
e-mail: hhromadzic@ffri.hr

\section{Sažetak}

U radu se pokušava ukazati na problem suvremene bračne zajednice kao ekonomsko i tržišno reguliranog entiteta $i$ jedne od rezultanti uznapredovanih kapitalisticko-komodifikacijskih procesa današnjice, što posredno uključuje obradu bliskih fenomena poput institucije obitelji, mita o vječnoj romantičnoj ljubavi, srodnih duša te zaruka, koje kontekstualno povezujemo s pitanjima ideologije konzumerizma, potrošačkog društva $i$ kulture. Zagovaramo tezu prema kojoj je ekonomska vrijednosna varijabla inherentna unutarnjoj strukturi i ustroju bračne zajednice kroz cijelu njezinu povijest, što naročito postaje evidentno uznapredovanom dinamikom kapitalističkih procesa tijekom posljednjih stotinjak godina.

Ključne riječi: brak, ideologija konzumerizma, kapitalistička komodifikacija, obitelj

\section{UVOD}

Našu epohu, tijekom posljednjih stotinjak godina, moguće je, između ostalog, tretirati i kao povijesno razdoblje koje je od presudne važnosti po pitanju pojačanih transformativnih procesa $\mathrm{u}$ institucijama bračne zajednice i obitelji. Te je promjene potrebno sagledavati u kontekstu dinamičnog razvoja potrošačkog društva pod okriljem kapitalističkog sustava. Naime, upravo su konzumeristički kapitalizam i potrošačka kultura, pokušat ćemo to pokazati kroz tekst, korisne uporabne platforme za stjecanje uvidâ u paletu karakteristika suvremene bračne zajednice i obitelji kreirajući pritom, između ostalog, i ideju o braku kao finalnom dokazu ljubavi. Pored okvira ideologije konzumerizma, potrošačke kulture i društva, ljubav, bračnu zajednicu i obitelj analitički je potrebno tretirati u kontekstu društveno-ekonomskih procesa komodifikacije, ${ }^{1}$ reapro-

\footnotetext{
1 Fenomen komodifikacije može biti polazišna točka prilikom interpretacije bračne zajednice kao proizvoda. Riječ je, naime, o procesu prema kojem se neki materijalan predmet ili osobno umijeće pretvaraju u robu na tržištu (Peračković, 2008). Važno je istaknuti da, prema suvremenoj ekonomskoj teoriji, pojmovi roba i proizvod nisu istoznačni. Pojam robe, osim fizičkih proizvoda uključuje i usluge, dok je proizvod opredmećeni rezultat ljudskog rada ostvaren radi izravnog ili neizravnog podmirenja neke potrebe (Rocco,
} 
prijacije i reifikacije osobnih ljudskih iskustava, emocija i doživljaja te legislativno-proceduralnih aspekata institucije braka, kao i hegemonijskih reprezentacija normativne obitelji, čime ih se sustavno preoblikuje i prilagođava. U najširem smislu, ove je procese moguće svesti pod sintagmu življeno iskustvo. ${ }^{2}$ Shodno tomu, temeljna nakana teksta jest ponuditi uvide i interpretacije nekih aspekata ekonomsko-tržišnih i komodifikacijskih trendova u suvremenim koncipiranjima ljubavi, braka i obitelji. Tim će analizama prethoditi dijelovi teksta posvećeni pregledu razvoja potrošačkog društva i kulture te osnovnih povijesno-društvenih karakteristika bračne zajednice i obitelji.

\section{RAZVOJ IDEOLOGIJE KONZUMERIZMA: OSNOVNA POVIJESNA RAZDOBLJA I OBILJEŽJA POTROŠAČKOG DRUŠTVA I KULTURE}

Istraživači i teoretičari konzumerizma nisu jedinstveni po pitanju jasnih početaka i prvih distinktivnih obilježja potrošačke kulture i društva. Istraživanja orijentirana ka povijesnom kontekstu, poput onog kojeg je izveo Grant McCraken, pronalaze elemente potrošačke kulture krajem 16. stoljeća u raskošnim ceremonijama na dvoru engleske kraljice Elizabete koje su prema ovim interpretacijama imale prepoznatljivu društvenopolitičku funkciju. ${ }^{3}$ Neki teoretičari idu korak dalje te upozoravaju kako je očite znakove konzumerističkih sindroma i potrošačkog lifestyla moguće pronaći i puno prije kraja 16. stoljeća, kroz primjere srednjovjekovne aristokracije ili u praksama europskih feudalaca u dugom rasponu od 5. do 12. stoljeća (Stearns, 2001:1-2). Drugi su pak skloniji povijesno pozicionirati prepoznatljive začetke potrošačke kulture u zadnja desetljeća 18 . stoljeća, u vrijeme tzv. romantizma. ${ }^{4}$

Nama su, u kontekstu glavnog interesa ovog testa - prikazu komodifikacijskih trendova bračne zajednice u društvenim uvjetima potrošačkog kapitalizma - ipak najvažniji elementi konzumerističke kulture u 20. stoljeću, sa svim pripadnim ekonomskim, političkim i društvenim obilježjima. Takvo mapiranje problema upućuje nas na nekoliko ključnih povijesnih razdoblja u proteklom stoljeću po ovom pitanju, započev-

u: Peračković, 2008:987). U svrhu problematiziranja nosive teze u radu, sukladno društvenoj proizvodnji odnosa, prikladan je upravo pojam proizvod.

2 Ovdje se naslanjamo na teze Jeremyja Rifkina iz knjige Doba pristupa. Rifkin terminom „doba pristupa“ označava epohu u kojoj gotovo svako proživljeno iskustvo i svaki aspekt ljudskog života postaju roba za koju se plaća. Više u: Rifkin (2005).

3 Ceremonijalna raskošnost je po jednoj strani imala za cilj simbolički legitimirati uspješnosti kraljičina vladanja, a po drugoj strani predstavljala je sugestivni naputak engleskoj aristokraciji kakav se tip praksi društvenog života od njih očekuje ukoliko imaju političke ambicije i aspiracije ka određenim pozicijama (Peračković, 2013:36-37).

4 Radi se o klasičnoj studiji Colina Campbella o romantičnoj etici i duhu suvremenog konzumerizma, već prema dobro poznatoj teoriji u kojoj romantična etika ranog modernizma predstavlja konzumerističkohedonistički, povijesno-usporedni pandan weberijanskoj protestantskoj radnoj etici ranog industrijskog kapitalizma (Campbell, 1987). 
ši s 20-im godinama 20. stoljeća. Objašnjavajući važnost ovog povijesnog perioda u kontekstu rađanja moderne potrošačke kulture, Don Slater naglašava nekoliko međusobno povezanih razvojnih faktora koji su na to utjecali: masovnu potrošnju, geografsko i društveno širenje tržišta, racionalizaciju oblika i organizacije produkcije (Slater, 1997:13). Isti autor smatra kako su 20-e godine prošlog stoljeća bile vjerojatno prvo povijesno desetljeće koje je proklamiralo ideologiju obilja i bogatstva, zaključujući da je „od 1920-ih svijet dijelom bio moderniziran kroz konzumpciju; sama potrošačka kultura bila je podložna ideji da svakodnevni život može i treba biti moderan..." (Slater, 1997:12). Radi se, dakle, o epohi u kojoj „konzumpcija i bivanje potrošačem više nisu opcije. To su neizbježne aktivnosti i identiteti onih koji žive u eri zrelog potrošačkog kapitalizma (približno od 1920-ih naovamo)“ (Cook, 2005:163). Također nije nevažan podatak kako upravo u ovom desetljeću američke banke započinju s poslovnom politikom odobravanja potrošačkih kredita s otplatom na obroke.

Prema uvidima Susan J. Matt, legitimizacija društvenog statusa potrošačke želje predstavljala je jedan od važnih faktora nadomještanja ispražnjene viktorijanske kulture obilježene između ostalog i protestantskom etikom kulture umjerenosti i potrošačke skromnosti $-s$ ranim trendovima moderne kulture u razdoblju između 1890. i 1930. $\mathrm{U}$ ovom periodu, paralelno $s$ društveno-gospodarskim procesima uznapredovale industrijalizacije, uzleta masovne tržišne maloprodaje i prvih naznaka popularne kulture, dogodio se presudan emocionalni preokret kod velikog broja Amerikanaca: želja za posjedovanjem potrošačkih objekata i njihovom konzumacijom nije više shvaćena kao nemoralan grijeh, već kao pozitivna stvar (Matt, 2003). Analizom djela Porgy američkog autora DuBose Heywarda, prvi put objavljenog 1925., kojeg smatra egzemplarnim primjerom tzv. negrotarian ${ }^{5}$ romana, Chip Rhodes na konkretnom primjeru pokazuje povijesni tijek konstrukcije konzumerističke želje u SAD-u u 20-im godinama prošlog stoljeća. Teza ovog autora je kako promicanjem ovakve ideologije, koja naravno nema antagonističke pretenzije spram korporativnog kapitalizma, „ljudska esencija pronalazi ekspresiju bilo gdje unutar potrošačkog tržišta“" (Rhodes, 1994:193).

Sljedeće važno razdoblje u razvoju potrošačkog društva u SAD-u, a što će potom, s kraćim vremenskim zakašnjenjem, bitno utjecati na srodne trendove u zapadnoj Europi, jest vrijeme netom nakon završetka Drugog svjetskog rata, rane 50-e godine. Ovaj je period naročito znakovit kada govorimo o modelu patrijarhalne obitelji te mjestu i ulozi žene-majke-domaćice u njoj. U socijalno-kulturalnom smislu, polovicom 20. stoljeća dolazi do širokog trenda suburbanizacije svakodnevnog života u Americi, promiče se ideal nuklearne obitelji s kućicom u predgrađu koja je ispunjena suvremenom kuhinjskom i svakom drugom modernom obiteljskom tehnologijom tog vremena. To pridonosi jačanju tada oslabjele američke industrije, posebice automobilske industrije koja doživljava rapidan procvat, sve naravno povezano s mobilnošću nove američke srednje klase i razvojem prvih modernih šoping centara (više o tome u: Hromadžić, 2008:47-48). Također, ekonomsko-političku pretpostavku ovakvih trendova u SAD-u

5 Pojmom negrotarians označavani su bijelci koji su podupirali crne umjetnike. 
neposredno nakon kraja Drugog svjetskog rata, predstavljali su Roosveltov New Deal i Keynesov makroekonomski projekt državnog intervencionizma - to jest jačanje uloge države u regulaciji tržišno-ekonomskih tokova. John Maynard Keynes, jedan od najvažnijih ekonomskih teoretičara 20. stoljeća, je iz primjera američkog gospodarskog kraha u dvadesetim godinama prošloga stoljeća izvukao zaključak da neke ekonomske probleme razvijenih kapitalističkih gospodarstava nije moguće rješavati bez neposrednog uplitanja i intervencije države, čime je njegova ključna studija The General Theory of Employment, prvi put objavljena 1936., postala svojevrstan kanon „političke ekonomije državnog kapitalizma" (Norčič, 1996:14).

Konačno, 80-e godine 20. stoljeća povijesna su epizoda „jednog od najjačih ponovnih otkrića konzumerizma" (Slater, 1997:10). Naime, u toj se epohi jasno isprepliću političke konture neoliberalizma (posebice kroz tzv. tačerizam i reganizam), gospodarske odlike tzv. postindustrijalizma (kognitivni kapitalizam, dominacija informacijskokomunikacijskih i servisno-uslužnih djelatnosti, prekarni rad, fleksibilna akumulacija kapitala...), socijalne karakteristike sve izrazitijeg individualizma i kulturalne dimenzije postmodernizma (masmedijski potpomognuta spektakularizacija i estetizacija svakodnevice, trijumf znaka i logike označavanja, visoko razvijena reklamna industrija, profesionalizacija marketinga i oglašavanja), koje nalaze svoje uporište u novom tipu potrošačke kulture - ideologiji konzumerističkog kapitalizma kao društveno-kulturalne dimenzije gospodarsko-političke matrice neoliberalizma.

U ovom je kontekstu potrebno podsjetiti na tri faze potrošačke kulture kako ih vidi i objašnjava Gilles Lipovetsky, čemu ćemo se još vratiti u tekstu. Prema njemu, prvu fazu, koja započinje oko 1880-ih i traje do kraja Drugog svjetskog rata, karakterizira oblikovanje velikih nacionalnih tržišta, unapređenje tehnika proizvodnje, ali i temeljita izmjena trgovačke filozofije. Naime, glavni cilj postaje ostvarivanje profita sniženjem prodajne cijene, to jest prodaja veće količine proizvoda uz nisku maržu, a ne mala količina proizvoda uz visoku maržu (Lipovetsky, 2008:16). Nadalje, razvitak masovne proizvodnje rezultirao je masovnim marketingom te konstituiranjem figure modernog potrošača, a potrošački se proizvodi standardiziraju. ${ }^{6}$ Poticaj masovne trgovine evidentan je i preko sve brže ekspanzije robnih kuća koje stavljaju naglasak na rapidnu izmjenu zaliha i niskih cijena te upravo s pomoću reklama započinju proces tzv. demokratizacije $\check{z} e_{j j e}^{7}$ (Lipovetsky, 2008:16). Lipovetsky drugu fazu potrošačke kulture poistovjećuje s

6 Standardizirani i distribuirani proizvodi na nacionalnim tržištima od tada nose imena dodijeljena im od strane proizvođača. To rezultira brojnošću poznatih brand marki kao što su Coca-Cola, American Tobacco, Kodak i sl. (Lipovetsky, 2008:17). Dogodio se iznimno indikativan prijenos jamstva kvalitete proizvoda koji se sada pripisuje proizvođačima, a ne garanciji prodavača. Drugim riječima, potrošač se započinje pouzdavati u marku proizvoda.

7 Pitanje demokratizacije želje i žudnje relevantno je u kontekstu problematike rada kao jedan od aspekata koji obuhvaća proliferaciju fenomena kulta tijela u svakodnevnim životnim sferama. Konkretnije, tiče se slobodnog pristupa građana većem broju sredstava seksualnog izražavanja, kao i artikulacije seksualne kulture koju krase raznolikost i pluralnost, vrijednosti itekako različite od onih koje tradicionalno egzistiraju u patrijarhalnom kapitalizmu (McNair, 2004:13). 
društvom obilja koje je rezultat ekonomskog rasta u razdoblju tzv. socijalne države blagostanja (od sredine 40-ih do sredine 70-ih godina prošlog stoljeća), odnosno podizanja razine produktivnosti rada i širenja fordističke ekonomije (Lipovetsky, 2008:18-19). Potrošačka demokratizacija u ovoj fazi doseže svoje vrhunce na način da za mnoge postaju dostupni proizvodi i usluge društva obilja poput automobila, televizije, kućanskih aparata, turističkih putovanja... Trgovačka revolucija, koja je obilježila drugu fazu, ogledala se u masovnoj distribuciji te izgradnji društva masovne potrošnje, a manifestira se kao društvo želje, hedonistički kult koji prati privatizaciju života konstituirajući pritom affluent society, odnosno društvo obilja (Lipovetsky, 2008:21). Od sredine 1970-ih godina naovamo svjedočimo trećoj fazi, Lipovetsky je naziva etapom hiperpotrošnje, a nju karakteriziraju prepoznatljivi komodifikacijski procesi svojstveni sustavu konzumerističkog kapitalizma, propagirajući pritom ideju tzv. ljudskih vrijednosti i emocija koje su neprocjenjive, no istovremeno imaju svoju cijenu. Također, potrošnja je sve više individualizirana, troši se u potrazi za srećom, kupuje se iskustvo, ideali zdravlja te vječne vitalnosti i mladosti...

\section{INSTITUCIJE BRAČNE ZAJEDNICE I OBITELJI: OSNOVNA POVIJESNA I DRUŠTVENO-EKONOMSKA OBILJEŽJA}

Brak je institucija s dinamičnom i varijabilnom prošlošću. ${ }^{8}$ Produljenje vrste, zaštita krvnog srodstva te regulacija privatnog vlasništva neka su od osnovnih obilježja koja karakteriziraju povijesne mijene i mutirajuće oblike bračne zajednice. Varijabilnost i transformativnost ove institucije ogleda se u brojnim zakonskim regulacijama i legislativnim uredbama bilo unutar vjerskih ili državnih institucija koje su neizostavno dio širih povijesnih, ekonomskih, političkih i kulturnih determinanti pojedine epohe. Primjereno široka, ali nedovoljno precizna definicija, određuje brak kao društveno priznatu i odobrenu seksualnu zajednicu između dvoje odraslih individua (Giddens, 2006:206). Redukcionizam ove definicije ogleda se u činjenici da u prvi plan po pitanju definiranja braka stavlja važnu, ali niti izbliza jedinu, karakteristiku ovog tipa zajednice - seksualnost. To je pitanje u direktnom suodnosu s konceptom monogamije - bračnim i ljubavnim odnosom s jednim partnerom/partnericom - koja se od srednjeg vijeka, a posebice od 11. stoljeća nadalje, nastoji nametnuti kao dominantan model pod strogim patronatom katoličke Crkve. ${ }^{9}$

8 Prvi zabilježeni dokazi o bračnim ugovorima i ceremonijama sežu 4000 godina unatrag i pronalazimo ih u Mezopotamiji. Brak je i tad bio sredstvo očuvanja moći, stjecanja zemlje te osiguravanja legitimnih nasljednika. Svrha braka bila je kontinuitet loze, što implicira riječ latinskog podrijetla matrimonium, koja je izvedenica riječi mater (majka); (The Week Staff, 2012).

9 Relativno je malo tragova o 'prirodnosti' monogamne ljubavi. Kod prvobitnih naroda ona je bila privremena te su parovi rijetko opstajali duže od deset godina, a djeca nisu živjela s oba roditelja. Poliginija pak, kao ljubavni odnos muškarca s više žena, istovremeno je bila mnogo češća budući da su se na monogamiju odlučivali najčešće siromašniji slojevi koji nisu imali sredstva za poliginiju. Tek s pojavom kršćanstva dolazi do apsolutističkih aspiracija ka monogamiji koja podrazumijeva vezu jedne žene i jednog muškarca za cijeli 
Nadalje, neodvojivo važna i u mnogim aspektima srodna bračnoj zajednici je institucija obitelji. Sam pojam obitelji mnogoznačan je, a u suvremeno doba najčešće se odnosi na užu i širu rodbinu čiji smo dio. U kontekstu ovog teksta uporabnim se nadaje marksističko-teorijsko viđenje i suodnosne kategorije podrijetla porodice, privatnog vlasništva i države. U istoimenom djelu Friedrich Engels, koristeći kao polazište studiju klasičnog američkog antropologa Lewisa Henryja Morgana Drevno društvo: istraživanja čovjekovog razvoja od divljastva i barbarstva do civilizacije, iznosi neke osnovne teze koje se bave evolucijom obitelji te pitanjem korelacije između monogamije, patrijarhata i privatnog vlasništva. Česta je laička i zdravorazumska tendencija promatranja monogamne obitelji kao vječne u povijesnom smislu. Nasuprot tomu, Morgan u svojoj knjizi pokazuje kako se ideja obitelji razvijala kroz sukcesivne stadije, od kojih je monogamija posljednja u seriji različitih formi (Morgan, 1877:393). Sukladno tomu, Morgan razlikuje pet povijesno-evolucijskih formi obitelji od kojih svaka utjelovljuje jedinstvenu instituciju braka. To su: obitelj iste krvi; ${ }^{10}$ obitelj punalua; ${ }^{11}$ obitelj na temelju uparivanja; $;^{12}$ patrijarhalna obitelj; ${ }^{13}$ monogamna obitelj. ${ }^{14}$ Prva, druga i peta forma bile su radikalne iz razloga što su bile dovoljno općenite i utjecajne da bi kreirale tri distinktivna sistema jednokrvnosti. Navedeni sistemi ukazuju na prethodno postojanje formi obitelji i braka, $s$ kojima su ujedno i povezani. Treći i četvrti sistem, obitelj temeljem uparivanja i patrijarhalna obitelj, činile su svojevrsnu sredinu te nisu imale pretjerani utjecaj kako bi stvorile novi ili pak modificirale tada aktualan sistem jednokrvnosti. No, Morganova studija ne pretpostavlja strogu odvojenost jednog tipa obitelji od drugih. Upravo suprotno,

život, u odbijanju spolnosti te pod nadzorom Crkve. U pozadini je demografska računica; težilo se kreiranju uvjeta za reprodukciju kršćanskih obitelji bez potrebe osvajanja velikog broja žena. Još važnije, vjerski ideal muškarca koji mora vječno voljeti jednog Boga te sukladno tome i jednu ženu, bio je izrazito pragmatičan i u ekonomsko-političkom kontekstu. Energija je bila usmjerena ka prakticiranju vjere, te naravno, kanaliziranju ekonomskog bogatstva prema Crkvi. Kroz razdoblje srednjeg vijeka teži se nametnuti monogamiju na Zapadu te monogamni brakovi u sve većoj mjeri postaju pravilo. Feudalne elite međusobno se vjenčavaju u svrhu očuvanja ili povećanja zemljišnih posjeda, dok seljaci, zbog izostanka valjanih sredstava kontracepcije, radikalnim mjerama poput nasilnih pobačaja i čedomorstva, pokušavaju smanjiti broj usta koja treba prehraniti. Usprkos tomu, još u 19. stoljeću svijetom u velikoj mjeri dominira poligamija te je još uvijek kontroverzna ženidba izvan svoje kaste, plemena i/ili klase, dok se brakovi nameću ženama i djeci. Naravno, Francuska je zemlja u kojoj s razdobljem racionalizma, humanizma, prosvjetiteljstva i sekularizma dolazi do mnogobrojnih promjena po ovim pitanjima. 1792. civilno vjenčanje postaje opće obvezatno pravilo u Francuskoj. Više o spomenutim i brojnim drugim aspektima monogamnih i poligamnih tipova ljudskih zajednica u povijesnom presjeku u: Attali, 2012.

10 Osnovana je temeljem mješovitog braka braće i sestara, vlastitih i kolateralnih, unutar grupe.

11 Osnovana je temeljem mješovitog braka nekoliko sestara, vlastitih i kolateralnih, s međusobnim muževima unutar grupe koji nisu nužno bili rođaci. Jednako je bilo i u obrnutom slučaju, odnosno u slučaju mješovitog braka braće s međusobnim suprugama, unutar grupe. U oba slučaja, grupa muškaraca bila je objedinjeno oženjena za grupu žena.

12 Pretpostavku za navedeno činio je brak između jedinki parova, no s izostankom ekskluzivne kohabitacije. Brak je nastavljen na uvjetnom zadovoljstvu obje strane.

13 Osnovana je na temelju braka muškarca sa više žena; nastavno, rezultirala je odvajanju žena. 14 Osnovana je na temelju braka između jedinki parova, te je uključivala ekskluzivnu kohabitaciju. 
prvi tip prelazi u drugi, drugi u treći, a treći u peti uz jedva osjetne gradacije (Morgan, 1877:394). Morgan polazi od teze prema kojoj su izloženi sistemi proizašli sukcesivno jedan iz drugoga, te da zajedno reprezentiraju evoluciju ideje obitelji.

Iz navedenog Engels izvlači zaključak da se evolucija obitelji u prethistorijskom periodu sastojala od kontinuiranog sužavanja kruga, koji je originalno obuhvaćao čitavo pleme, unutar kojeg je naposljetku prevladala bračna zajednica između dvaju spolova (Engels, 1978:1238). Svaka vrsta grupnog braka finalno se pokazala neodrživom. Na kraju je opstala samo jedna, ona koja označava par, molekulu, s raspuštanjem koje prekida brak sam po sebi. Na tragu toga moguće je zapitati se koliko individualna seksualna ljubav ima veze s podrijetlom monogamije. Nadalje, monogamna obitelj koja se razvija iz obitelji uparivanjem u tranzicijskom periodu od srednjeg do gornjeg stadija barbarstva, bila je svojevrsni znak začetka civilizacije. Njezin temelj leži u vladavini muškarca u cilju reprodukcije $s$ neosporivim očinstvom koje je zahtijevano u svrhu omogućavanja da djeca nasljeđuju očevo imanje sukladno statusu njegovih prirodnih nasljednika ${ }^{15}$ (Engels, 1978:1247). Sukladno tomu, monogamna obitelj, koja nipošto nije bila rezultat individualne spolne ljubavi, odraz je braka koji, kao i u prethodnim razdobljima, ostaje brakom iz pogodnosti i udobnosti. Obitelj nastala iz monogamnog braka bila je prva forma obitelji temeljene prvenstveno na ekonomskim, a ne prirodnim uvjetima; prevagu je odnijelo privatno vlasništvo nad prvobitnim, iskonskim zajedničkim vlasništvom (Engels, 1978:1248-1249). Sukladno marksističkoj interpretaciji ovih problemskih izazova, Engels iznosi tezu prema kojoj je kapitalizam uređenje u kojem materijalni i ekonomski faktori podupiru subordinaciju žena muškarcima, a navedeno proizlazi iz ideje prema kojoj su korijeni patrijarhata sadržani u konceptu privatnog vlasništva ${ }^{16}$ (Engels, u: Giddens, 2006:470). Prema Marxu i Engelsu, podjela rada prvobitno nije bila ništa drugo nego podjela rada u spolnom aktu, a zatim podjela rada koja se vrši sama po sebi, s pomoću prirodnih sklonosti, kakva je primjerice tjelesna snaga (Marx i Engels, 1978:310). Nastavno na tu tezu, Engels iznosi tvrdnju prema kojoj se prva klasna suprotnost u povijesti poklapa s razvojem anta-

15 Važno je istaknuti da su, prema Engelsu, patrijarhat, privatno vlasništvo i monogamija usko povezani budući da patrijarhalna monogamna obitelj štiti vlasništvo u posjedu muškarca. Monogamna obitelj ekonomski privezuje ženu, te rađanjem i podizanjem djece osigurava reprodukciju kapitalizma kreiranjem nove radne snage. $U$ ovu problematiku neizostavno ulazi i status žene kroz povijest čovječanstva. Naime, ideja prema kojoj je žena od samog začetka društva bila rob muškarcu, prema Engelsu je jedna od apsurdnijih kojima svjedočimo. Žene su zauzimale važne i poštovane pozicije u 'primitivnim' vremenima, a njihova moć bila je u ekskluzivnom prepoznavanju žene kao majke, dok je determiniranje biološkog oca bilo iznimno teško (Engels, 1978:1239).

16 Prema Engelsu, kapitalizam intenzivira patrijarhalni model na način da koncentrira moć i bogatstvo u rukama manjeg broja muškaraca. Nadalje, kapitalizam ima mnogo veći utjecaj na patrijarhat od prijašnjih društvenih sistema budući da kreira veliku količinu bogatstva koje muškarce čini moćnijima u kontekstu onih koji privređuju (Engels, u: Giddens, 2006:470). No, nipošto manje važan aspekt odnosi se na jedan od uvjeta opstanka kapitalističkog uređenja u vidu definiranja muškaraca i žena kao potrošača. U tom kontekstu, politička ekonomija kapitalizma oslanjala se na žene i njihov rad kod kuće te potrošnju i konzumaciju brojnih proizvoda, kao i eksploataciju muškaraca u vidu niskih nadnica za obavljeni rad, dok je ženski rad u kući redovito neplaćen, 'nevidljiv'. 
gonizma muža i žene u monogamiji, a prvo klasno ugnjetavanje - ugnjetavanje ženskog spola od strane muškog. Pritom je monogamija bila veliki povijesni napredak, no ona je istodobno (uz robovlasništvo i privatno vlasništvo), otvorila epohu koja traje do danas i u kojoj je svaki napredak ujedno i relativni nazadak, u kojoj se blagostanje i razvoj jednih ostvaruju stradanjem i suzbijanjem drugih. Upravo stoga monogamija predstavlja stanični oblik civiliziranog društva na čijem primjeru možemo proučavati prirodu suprotnosti i proturječnosti koje se u punoj mjeri razvijaju u tom društvu (Engels, 1978:1249). Engelsova je ideja da se potpuna sloboda stupanja u brak može provesti tek uklanjanjem kapitalističke proizvodnje i njome stvorenih imovinskih odnosa, čime bi se odstranili svi drugi motivi osim uzajamne naklonosti (Engels, 1978:1259).

U kontekstu naše rasprave treba barem spomenuti primjer tzv. idealne viktorijanske obitelji u 19. stoljeću. Opće vrijednosne varijable koje se najčešće pripisuju ovom modelu, poput stabilnosti, vjernosti, discipline i moralnosti, obilježene su brojnim problematičnim mjestima. Brakovi su tada u prosjeku trajali dvanaest godina, mortalitet je bio izrazito visok, a disciplina koja je u kasnijim razdobljima služila kao ogledni primjer manifestirala se visokom razinom autoriteta roditelja nad djecom čije su metode odgoja nerijetko bile diskutabilne (Giddens, 2006:210). Povijesno mlađi model tzv. idealne obitelji vezan je uz polovicu 20. stoljeća i spomenuto patrijarhalno uređenje u kojem je muškarac bio odgovoran za privređivanje i uzdržavanje obitelji, dok su žene često obnašale ulogu kućanica, no ne bez brojnih frustracija i obiteljskih tenzija. ${ }^{17}$ Vidjeli smo već u kolikoj je mjeri patrijarhalno uređenje obitelji bila prisutna i konzistentna forma bračne zajednice tijekom povijesti. ${ }^{18}$

No, tradicionalna uloge žene kao majke i kućanice te muškarca kao glave obitelji koji privređuje, uzdrmane su u drugoj polovici 20. stoljeća, a nekad obvezujuća priroda braka postaje sve više tek opcionalna. ${ }^{19}$ Pojam obitelj započinje obuhvaćati različite, no

17 Treba napomenuti da su okolnosti Drugog svjetskog rata dovele do masovnog zapošljavanja žena na relativno dobro i stabilno plaćene javne poslove (administracija, obrazovanje, zdravstvo, socijalna skrb i tomu slično), no nakon povratka muškaraca s ratišta pojavljuje se društveno-ideološka i spolno-rodna tenzija prouzrokovana idejom da je muškarcima potrebno 'vratiti' te poslove. U tom se kontekstu pojavljuje javno-medijski fabriciran lik žene-majke-kućanice unutar tzv. idealno-tipskog modela nuklearne obitelji, što je opet dio šireg konteksta nastanka masovnog potrošačkog društva u SAD-u i modernih šoping centara kao novog tipa pseudo javnog prostora, prvenstveno namijenjenog upravo ženama.

18 U mnogim azijskim i afričkim zemljama patrijarhalno uređenje i dalje je eksplicitno prisutno, a nerijetko ga je moguće pronaći i u zapadnim društvima, pri čemu je u određenim krajevima mnogo izraženije negoli u drugima. Prema provedenom istraživanju dobrotvorne fondacije Thomson Reuters Foundation, četiri najopasnije zemlje za žene danas su Afganistan, Kongo, Pakistan i Indija. Istraživanje je uključilo 213 profesionalaca distinktivnih zanimanja koji su rezultate rangiranja najopasnijih zemalja donijeli na temelju cjelokupne percepcije opasnosti u istima, kao i temeljem postojanja šest rizičnih kategorija koje su, kako slijedi: prijetnje bolesti, seksualno zlostavljanje, fizičko/psihičko zlostavljanje, opasne prakse ukorijenjene u kulturi, tradicija i/ili religija te izostanak ekonomskih sredstava i trgovina robljem. Spomenuta organizacija zalaže se za nezavisno novinarstvo, ljudska prava i osnaživanje prava žena (Press Trust of India, 2011).

19 Upravo je opcionalnost jedan od faktora koji je udario temelje proliferaciji u uvodu spomenutog stava o partneru/partnerici kao zamjenjivim/zamjenjivom, dodijelivši mu/joj status ekvivalentan svojevrsnom proizvodu, što će biti detaljnije analizirano u nastavku teksta. 
često i fragilne aranžmane koji definiraju tzv. postmodernu obitelj; samohrane majke, parovi u izvanbračnoj zajednici i homoseksualni partneri čine svojevrsnu ediciju društvenoj normi heteroseksualnih parova u braku (DiFonzo, 2011:524). Sukladno brojnim društvenim promjenama koje su stupile na scenu tijekom posljednjih četiri-pet desetljeća, došlo je do diskrepancije u strukturi bračne zajednice. Percepcija obitelji promijenila se kao i ideja o normativnoj obitelji koja je postala redundantnom i rezultirala je pitanjem jesu li obiteljske vrijednosti temeljno relativizirane (Scott, 2006:2-3). Navedenom su pogodovali brojni elementi od kojih svakako valja izdvojiti veća radna, socijalna i politička prava žena; uzlet feminističkih pokreta; razlike u prihodima između muškaraca i žena koje nisu anulirane, ali su ipak umanjene; višu razinu seksualnih sloboda; smanjenu učestalost dogovornih brakova; te uvelike smanjen utjecaj roditelja, rodbine i drugih srodnih grupa na intimnu sferu pojedinaca i pojedinki (Giddens, 2006:212).

Također, već spomenutim osjetnim slabljenjem religijskih autoriteta uslijed društvenih i ekonomskih promjena od druge polovice 20. stoljeća nadalje, tradicionalna percepcija braka kao sakralne institucije bitno se izmijenila. Konzervativne vrijednosti poput bračne zajednice kao preduvjeta za stupanje u seksualne odnose, pretpostavka o braku kao cjeloživotnoj zajednici bez obzira na okolnosti, klasični patrijarhalni model i tomu slično, doživjeli su bitne i nepovratne modifikacije tijekom posljednjih nekoliko desetljeća. Naime, ako privilegiju stupanja u brak još uvijek najčešće imaju heteroseksualni parovi, to je pravo zakonski omogućeno i homoseksualnim parovima u nekim državama poput Nizozemske, Belgije, Španjolske, Norveške, Švedske, Ujedinjenog Kraljevstva, Argentine i Brazila. No, na drugoj strani istovremeno svjedočimo aktualnim neokonzervativnim trendovima u vidu pokušaja ponovne sakralizacije modela braka isključivo određenog heteroseksualnim modelom. Tako su neke države otišle toliko daleko da su provođenjem referenduma donijele odluku o unošenju definicije braka kao isključive zajednice muškarca i žene u Ustav. ${ }^{20}$

\section{KOMODIFIKACIJA LJUBAVI I EKONOMIJA BRAČNE ZAJEDNICE: RAZRADA FENOMENÂ}

Ljubav, jedna od esencijalnih ljudskih emocija, predmet je brojnih polemika, ali istovremeno i fenomen koji u društvu ima status samorazumljivog, nečeg što se često poima kao mogući smisao egzistencije. Slijedom toga, kult idealne ljubavi podrazumijeva stabilnu i postojanu vezu te ispunjen život udvoje. No, paradoks koji se pritom može primijetiti nalazi se u činjenici prema kojoj se ljubav pojavljuje kao ideal koji ujedno destabilizira i jača želju; s druge strane, ljubav funkcionira kao agens samoograničenja i regulacije poriva (Lipovetsky, 2008:153). Lipovetsky će također ustvrditi da je u srži ljubavne sreće narcistički poriv, potreba osobe da bude zapažena, željena i obožavana zbog

20 Brak je definiran isključivo kao zajednica između muškarca i žene u deset europskih zemalja, od kojih je šest članica Europske unije. Riječ je o Poljskoj, Mađarskoj, Bugarskoj, Latviji, Litvi te Hrvatskoj. 
sebe same, naše želje da nekome predstavljamo nezamjenjivu, nenadoknadivu osobu (Lipovetsky, 2008:154). Važnost problematiziranja ljubavi kao koncepta jest u tome da se naprosto radi o socijalnom konstruktu koji mijenja svoje forme sukladno dominantnim tokovima 'duha vremena' pojedine epohe na pojedinom prostoru, a samim time ovisno i o mjestu koje ideja ljubavi zauzima u društveno-ekonomskoj i kulturalno-normativnoj matrici.

Proliferacija ideje o ljubavi kao jednom od temeljnih razloga za stupanje u brak, dosegla je široke razmjere u 20. stoljeću, a trendovi naravno sežu i do današnjeg vremena, s tendencijom intenziviranja. Između ostalog, ljubav se cijelim tijekom 20. i ranog 21. stoljeća pokazuje jednom od najprofitabilnijih ideja moderne i postmoderne, svojevrstan eliksir kapitalističkog sustava. Vizija prave romantične ljubavi ${ }^{21}$ postala je vodilja u potrazi za smislom i ispunjenjem života, nerijetko s težnjom ka braku kao kruni ljubavnog odnosa. Kao što je već ukazano, a bit će problematizirano i u nastavku rada, ljubav i brak se tijekom posljednjih stotinjak godina doista isprepliću, no ne u smislu 'čiste, nedužne' romantične vizije njihove 'prirodne' simbioze, već na način komodificirane vrijednosti $s$ jasnom tržišnom računicom. Stoga ne iznenađuje da je intenziviranje modernih trendova potrage za 'pravom' ljubavlju okrunjenom jedinstvenim bračnim odnosom moguće datirati u rana desetljeća prošlog stoljeća, razdoblje koje smo označili kao epohu uskrsnuća modernog potrošačkog kapitalizma, ali i vrijeme kada su na scenu stupile ideje o srodnim dušama.

Pojam srodna duša postao je idiomom svakodnevnog diskursa današnjice. Definicija nije pretrpjela velike varijacije protekom vremena, a razlike je eventualno moguće pronaći u ponekim finesama koje se tiču samog koncepta. Riječ je o mitu koji promovira ideju o postojanju osobe koja nam je sudbinski predodređena, koja će nas upotpuniti. Ideja srodne duše implicira potragu za osobom koja će u potpunosti prihvatiti nas i naše osobine, a međusobnim pronalaženjem naši će životi zadobiti smisao. ${ }^{22}$ Ukoliko se priklonimo pretpostavci prema kojoj je ljubav mehanizam koji služi validaciji sebstva, ideja

21 Širenje ideje o romantičnoj ljubavi treba tražiti u široko rasprostranjenoj anglo-američkoj književnosti 19. stoljeća. Popularizirale su je, primjerice, intelektualne figure poput Lorda Byrona i Elizabeth Barrett Browning (više o tome u: Bruns, 2013). Općenitije, romantizam je uvriježen naziv za književni pravac koji se javio u gotovo svakoj europskoj zemlji i SAD-u i trajao od 1750. do 1870. godine. Karakterizirao ga je otpor spram utemeljenih pravila, zakona i dogmi koji su obilježili klasicizam i neoklasicizam 18. stoljeća. Termin romantično javlja se u engleskom jeziku u 18. stoljeću i prvotno je upućivao na karakter srednjovjekovnih romanci (romancelike). Romantičari su važnost pridavali individualnoj ekspresiji te jedinstvenosti izražaja koji se ne povode za utemeljenim predodžbama i idejama. Vjerovali su da muškarce i žene trebaju voditi emocije, a ne hladna, apstraktna pravila koja je uspostavilo buržoasko društvo (Schwartz, 1999).

22 Ideja srodnih duša seže daleko u prošlost, nalazimo je još kod Platona. U djelu Ijon; Gozba; Fedar, u dijalogu Gozba ili o ljubavi, Aristofan nas uvodi u priču o srodnim dušama. Navodi kako su inicijalno ljudi imali četiri ruke i četiri noge te dva lica na glavi, a postojala su tri ljudska roda; muški, ženski i androgini. Muški rod je prvobitno potekao od sunca, ženski od zemlje, a androgini od mjeseca. Budući da su ljudi bili snažni te su se odvažili napasti bogove, Zeus ih je odlučio kazniti na način da ih je prepolovio. Posljedično tomu, bili su slabiji te od tada čeznu za svojom drugom polovicom koja ih sastavlja u prvobitnu prirodu i teži da od dvoje napravi jedno (Platon, 1970:52-55). 
o srodnoj duši može biti tretirana i kao simptom spomenutog narcizma. Naime, pronalaskom druge osobe i zaljubljivanjem u nju, mi se na neki način zaljubljujemo u sebe same, budući da su najčešće upravo sličnosti i interesi koje dijelimo $s$ dotičnom osobom elementi koji čine konstitutivne dijelove naše osobe. Kada su emocije uzvraćene, ego dobiva snažan poticaj temeljem validacije koju je primio od druge strane. Suprotno tomu, neuzvraćene emocije rezultiraju povrijeđenim egom; sebstvo nije uvaženo već je odbačeno. Spomenuta popularizacija ideje romantične ljubavi te proliferacija koncepta srodnih duša, od 20-ih godina prošlog stoljeća nadalje, postajale su sve važnijim segmentima izgradnje potrošačkog društva. Selekcija partnera postupno se transformirala u smjeru sve važnije i zahtjevnije prakse pojedinaca i pojedinki koji tragaju za vlastitim sretnim završetkom.

Pri svemu tome suvremeni modeli komodifikacije ljubavi u bitnoj mjeri bivaju određeni aktualnim fenomenima koji su povezani i s medijsko-novotehnološkim, kao is trendovima globalizacije. Proliferacija novih medijsko-distributivnih kanala i sadržaja te proizvoda i usluga u eri novih medija i medijskih tehnologija, odigrala je važnu ulogu u razvoju industrije odnosa. ${ }^{23}$ Što se pak tiče globalizacije i njezinih karakteristika - kao neraskidivo vezanog seta fenomena s prethodno spomenutim kontekstom (su)odnosa novih medija i novih modela bračnih zajednica - interpretiramo li ju kao ciklični fenomen, što podrazumijeva tezu prema kojoj je globalizacija proces dugog povijesnog trajanja do današnjih dana (Eštok i Bzdilova, 2011:44), varijabilne forme braka i obitelji, kao što smo u radu već pokazali, pronaći ćemo u svim historijskim razdobljima uz specifična obilježja karakteristična za svaku pojedinu epohu. U tom smislu, važna karakteristika našeg razdoblja je pojačana društvena važnost novomedijske tehnološke komponente. Naime, opće je mjesto da je jedno od osnovnih obilježja globalizacije upravo važna uloga novomedijske digitalne tehnologije i Interneta prilikom nadilaženja geografskih i fizičkih udaljenosti. Zahvaljujući ubrzanom razvitku suvremenih elektroničkih medija, komunikaciju je moguće uspostaviti gotovo trenutačno te ju provoditi bez teškoća (Croteau i Hoynes, 2003:338). Realizacija interakcija s ljudima iz različitih dijelova svijeta nikada nije bila jednostavnija, društvene mreže, forumi, chat i oglasi mnogobrojni su izvori i sredstva komunikacije putem kojih se korisnici povezuju u svrhu poslovnih kontakata, razonode, pronalaženja poznanika/prijatelja/kolega, pronalaska odgovarajućih usluga i proizvoda, ali i s ciljem upoznavanja potencijalnog partnera/partnerice. Opcije beskonačnih ponuda

23 Posebice svjedočimo svojevrsnoj postmodernističko-novomedijskoj modifikaciji nekih starijih običaja poput dogovorenih brakova. Takve je trendove u novije vrijeme moguće prepoznati u fenomenima poput narudžbe online mladenki. Radi se o sve većem broju internet stranica koje nude mogućnost selekcije potencijalne mladenke - najčešće iz zemalja koje karakteriziraju mnogo teže i lošije ekonomske i socijalne situacije - za strane klijente iz zapadnih zemalja, najčešće iz SAD-a. Model online narudžbe mladenki oslanja se na stereotipe i transnacionalnu ekonomsku nejednakost $s$ ciljem ostvarivanja i održavanja profitabilnog tržišta (Chun, 1996:1156). Implikacije ovog modela su mnogostruke: od pitanja regulacije i legislative poslovanja stranica online mladenki, preko problema komodifikacije roda, do modela online mladenki kao paravana globalne trgovine ženama, ali i širenja matrice profitabilnosti putem promoviranja navodnih liberalno-kulturoloških vrijednosti. 
vezanih za zaruke i vjenčanja te parove općenito, nalaze se gotovo posvuda; na televiziji, u novinama/časopisima, na plakatima, brojnim reklamama te internetskim stranicama, trgovačkim centrima i manjim obrtima pa čak i ugostiteljskim objektima. Ljubav, život u dvoje i sretna obitelj samo su neke od fraza koje susrećemo u svakodnevnom životu, a koje su dio distinktivnih marketinških taktika i metoda.

Dakle, mitologije ljubavi i idealnog odnosa aktualiziraju se u skladu s novim društvenim, ekonomskim i kulturalnim trendovima. Izraženo promicanje figure homo eroticusa u trećoj fazi potrošačkog kapitalizma, dakle od 70-ih godina naovamo, prema Lipovetskom nije izazvalo brodolom ljubavnog diskursa (Lipovetsky, 2008:184). Naprotiv, isti je osnažen te svjedočimo psihologizaciji seksualnosti i života para. $S$ obzirom da su naše egzistencije u gotovo svim sferama određene uvjetima koje određuje kapitalističko uređenje, komodificiran model ljubavnih odnosa može poslužiti kao jedan od tih primjera. Selekcija partnera/partnerice danas je gotovo istovjetna odabiru proizvoda; praksom izlazaka, odnosno spojeva, ljudi na temelju vidljivih i percipiranih karakteristika donose odluku o stupanju u potencijalan odnos. Odluci o eventualnoj kohabitaciji prethodi svojevrsna pokusna vožnja, osobito među osobama koje teže stupanju u bračnu zajednicu. ${ }^{24}$

Ovdje barem nakratko treba spomenuti i ekonomske teorije bračne zajednice koje obuhvaćaju širok spektar pretpostavki i institucionalnih ograničenja, uključujući brojne ideje o ulozi muškaraca i žena, ideala ljubavi i bioloških ograničenja (GrossbardShechtman, 2003:2). U studiji Grossbard-Shechtman sumirani su bazični teorijski konstrukti koje ekonomisti koriste prilikom analize braka. To su: analize cijene/koristi ${ }^{25}$; teorija igre ${ }^{26}$; i marketinskka analiza ${ }^{27}$ (Grossbard-Shechtman, 2003:2-3). No, direktan

24 Zajednički život prije braka sve je češća opcija parova. Primjerice, prema izvješću američkog Centers for Disease Controle and Prevention, između 2006. i 2010. 48\% heteroseksualnih žena u dobi između 15 i 44 godina nisu bile udane za svog sadašnjeg supruga kada su prvi put počeli živjeti zajedno. To je razlika u odnosu na postotak iz 2002. godine koji je iznosio 43\%, te iz 1995. kada je iznosio 34\% (Rettner, 2013). 25 Analiza cijene/koristi spada u kategoriju teorija racionalnog izbora, a u ovom je kontekstu zanimljiva iz nekoliko razloga. Selekcija potencijalnog partnera u mnogome se temelji na procjeni karakteristika i osobina koje su dio naših osobnih preferencija i ukusa. Pri pokušaju interpretacije ove varijable, ona je nerijetko u stanovitoj korelaciji s osobom izvan našeg ranga, što uključuje i pitanje vrijednosti osobe. Izrazi poput osoba izvan našeg ranga podložni su višestrukim interpretacijama. Postojanje takvih (i sličnih) sintagmi implicira ideju egzistencije sustava rangiranja prema čijim parametrima donosimo sud o prikladnosti potencijalnog partnera. No, pritom se javljaju barem dva problema; sustav rangiranja i njegovi parametri podrazumijevaju pitanje postojanja nekogalnečega tko/što je sustav i kreirao, kao i pitanje društvenog konteksta unutar kojeg se ta konstrukcija odvijala.

26 Teorija igre aplikativna je na ovom mjestu jer institucija braka involvira mjeru strateškog ponašanja, neovisno o ciljevima same zajednice. Igra sugerira sferu zabave, razonode, znatiželje, određenu dozu bezbrižnosti. Suženo u okvire ove rasprave, pod kategoriju igre spadali bi rituali udvaranja. Udvaranje je svojevrsna strategija koja podrazumijeva precizan plan i/ili metodu koja za svrhu ima postizanje partikularnog cilja tijekom dužeg vremenskog perioda (Merriam-Webster, 2014). Naravno, strategije variraju sukladno kulturi i društvenom kontekstu, a uvelike ovise i o pojedincu/ki te ih je gotovo nemoguće svesti pod univerzalne kategorije.

27 Marketinška analiza bavi se pitanjem konkurencije koja na ovom mjestu, sukladno trendovima komodifikacije odnosa, implicira postojanje tzv. tržišta partnera i partnerica koje je, kao i svako drugo tržište, pod- 
putokaz ka osnovnom interesu ovog teksta - razumijevanju komodifikacijskih trendova vezanih uz moderni brak; može biti prepoznat u suvremenim komercijalnim manifestacijama obreda koji često prethodi braku, a to su zaruke.

Pritom nas posebno zanima simbolički materijalni objekt koji je i direktna asocijacija na riječ zaruke - zaručnički prsten; posebice onaj s najvišom razinom materijalne i simboličke vrijednosti, dijamantni. Dijamantni prsten nerijetko je smatran univerzalnim simbolom ljubavi. ${ }^{28}$ Povezivanje dijamanta i ljubavi potaknuto je romantičarskim raspoloženjem ranog 19. stoljeća, na koje je ujedno utjecala i kraljica Viktorija poznata po strasti prema dijamantima (Becker, n.d.). S 20. stoljećem zaručnički prsten postaje sastavni dio zaruka, neizostavna simbolika ekvivalentna prethodno spomenutim idealima srodnih duša te vječne ljubavi. Draguljari su zaslužni za promoviranje ideje o vjenčanom prstenu muškarca kao i o uključivanju običaja razmjene vjenčanog prstenja za vrijeme obreda. Prsten mladoženje, ženama je marketinški prezentiran u smislu simboličkog označavanja posjedovanja budućih muževa (Montemurro, 2008). ${ }^{29}$

ložno kompeticiji. Svaka individua stoga teži pronaći sebi najpodobnijeg partnera, sukladno restrikcijama nametnutim od strane tržišta (Becker, 1974:300). Pritom takvo tržište više nije ograničeno na druženja i upoznavanja na specifičnim lokacijama poput klubova, kafića i sličnih mjesta za zabavu, već se rapidno širi sferama svakodnevice, nerijetko vođeno logikom prema kojoj je srodnu dušu moguće upoznati bilo gdje. Proces natjecanja za potencijalne partnere/ice moguće je promatrati iz univerzalne perspektive, no njegova forma itekako varira ovisno o kulturnim kontekstima. Na Zapadu ga možemo locirati u barove i kafiće, svečanosti, promocije i zabave te slična društvena okupljanja. U Indiji pak, vjerojatnija je opcija promatranja i prikupljanja informacija temeljem lokalnih novina te fotografija slobodnih muškaraca i žena u njima. 28 Simbolika prstena ovisna je, naravno, o kontekstu. Budući da je okrugao, u mnogim kulturama reprezentira vječnost; u slučaju vjenčanja, riječ je o ideji kontinuirane ljubavi para i njihovu jedinstvu. Alternativna simbolika prstena, vezana uz područje magije, upućuje na partikularne moći koje osoba posjeduje, dok u religijskoj perspektivi označava vječnost i savršenost Boga. Nadalje, stoljećima je prsten bio simbol statusa i kraljevskog podrijetla, uzevši u obzir činjenicu prema kojoj običan puk nije imao sredstva s pomoću kojih bi ga mogao platiti. Za neke je prsten simbol reinkarnacije, dok za druge predstavlja cirkularnost i prolaznost života (više o tome u: Chevalier i Gheerbrant, 2007).

29 No, ovaj simbol romantike i vječne ljubavi u zapadnom svijetu, ima potpuno drugačija obilježja i efekte na mjestima njegova iskapanja. Naime, dvije trećine svjetskih dijamanata potječu iz Afrike, iz brojnih konfliktnih zona, a njihova se prodaja koristi u svrhu financiranja operacija raznih diktatora i vladara (Marati, 2012), dok uvjeti rada u rudnicima dijamanata podsjećaju na robovlasničke. Istovremeno, industrija dijamanata bilježi visoke profite, iako su naznake govorile drugačije. Sve do 1870-ih godina tržište dijamanata trpjelo je oskudicu, ali su potom otkriveni mnogobrojni dijamantni rudnici pokraj rijeke Orange u Južnoj Africi. Ova su otkrića mogla dovesti do drastičnog pada tržišta dijamanata, svodeći ih na polu-drago kamenje. Dogodilo se suprotno. Rudarski lobi povezao je interese u jedan entitet pod nazivom De Beers koji se dokazao kao najuspješnije organiziran kartel moderne trgovine, a uspjeh je polučio kontroliranim cijenama, ograničenim zalihama te perpetuacijom aspirativnih kvaliteta dijamanata (Marati, 2012). De Beers je marketinšku kampanju fokusirao na SAD te je 1938. angažirao tada vodeću agenciju za oglašavanje u svrhu kreiranja nove marketinške kampanje koja je rezultirala izrazito uspješnom reklamnom strategijom. Podloga ove strategija bila je bazirana upravo na ideji povezivanja dijamanata sa simbolikom romantičnih veza i vjernosti (Marati, 2012). 


\section{NA MJESTU ZAKLJUČKA}

U radu smo pokušali ukazati na problem suvremene bračne zajednice kao ekonomsko i tržišno reguliranog entiteta i jedne od rezultanti uznapredovanih kapitalističkokomodifikacijskih procesa današnjice, što je posredno nužno uključilo obradu bliskih fenomena poput institucije obitelji, mita o vječnoj romantičnoj ljubavi, srodnih duša te zaruka, koje je bilo potrebno kontekstualno povezati s pitanjima ideologije konzumerizma, potrošačkog društva i kulture. Analiza je, dakle, morala uključiti ekonomskopolitičku, društvenu i kulturalnu perspektivu, ali su neka problemska pitanja nužno ostala tek naznačena i vrijedilo bi im se detaljnije posvetiti. Takva su, primjerice, pitanja reprezentacije ideje ljubavnog para, konstruiranja sebstva u braku, komercijalnih aspekata obreda vjenčanja, procesâ izgradnje društvene mikro realnosti u bračnoj zajednici... Pritom ne zagovaramo tezu prema kojoj je institucija braka isključivo i posljedično određena eksternim utjecajima razvojne dinamike kapitalizma te potrošačke ideologije i kulture. Naime, budući da je ekonomska vrijednosna varijabla inherentna unutarnjoj strukturi bračne zajednice kroz cijelu njezinu povijest, što smo pokušali pokazati i u radu, uznapredovala matrica kapitalističkih procesa tijekom posljednjih stotinjak godina stvara bazične strukturne preduvjete koji ove karakteristike čine prepoznatljivim i dinamičnijim. U današnjoj epohi pojačane komodifikacije i komercijalizacije međuljudskih odnosa, emocija, ljubavi, prijateljstava... sve ustrojeno logikom sveopće dominacije profita, brak, ne po prvi puta, prolazi kroz intenzivne procese promjena koje su sukladne trendovima aktualnog hegemonijskog poretka, putem čega ova institucija postaje tek jedan od njegovih reprezentativnih simptoma.

\section{LITERATURA}

Attali, J. (2012). Ljubavi: povijest muško-ženskih odnosa. Zagreb: Alfa.

Becker, G. S. (1974). A Theory of Marriage. U: T. W. Schultz (ur.), Economics of the Family: Marriage, Children, and Human Capital. URL: http://www.nber.org/chapters/c2970.pdf (siječanj 2015.)

Becker, V. (n.d.). The history of engagement rings. URL: http://www.debeers.com/engagement_siječanj 2015.2

Bruns, J. R. (2013). Can You Have More Than One Soul Mate? URL: https://www. psychologytoday.com/blog/repairing-relationships/201304/can-you-have-moreone-soul-mate (siječanj 2015.)

Campbell, C. (1987). The Romantic Ethic and the Spirit of Modern Consumerism. Oxford: Basic Blackwell.

Chevalier, J. i Gheerbrant, A. (2007). Rječnik simbola. Zagreb: Naklada Jesenski i Turk.

Chun, C. S. Y. (1996), The Perpetuation of Transnational Economic Inequalities and Stereotypes. The Mail-Order Bride Industry, 17(4):1155-1208.

Cook, D. T. (2005). Consumer Culture. U: M. D. Jacobs i H. N. Weiss (ur.), The Blackwell Companion to the Sociology of Culture. Oxford: Blackwell Publishing. str. 160-175. 
Croteau, D. i Hoynes, W. (2003). Media/Society: Industries, Images and Audiences. London: Sage Publications, Inc.

DiFonzo, H. J. (2011). How marriage became optional: cohabitation, gender and the emerging functional norms. Rutgers Journal of Law \& Public Policy, 8(3):521-672.

Engels, F. (1978). Porijeklo porodice, privatnog vlasništva i države. U: A. Dragičević, V. Mikecin i M. Nikić (ur.), Glavni radovi Marxa i Engelsa. Zagreb: Svjetlost, Biblioteka Veliki mislioci. str. 1213-1320.

Eštok, G. I Bzdilová, R. (2011). Globalization - An Old or a New Phenomenon. U: M. Premsvl i D. Tomaš (ur.), The Scale of Globalization. Think Globally, Act Locally, Change Individually in the $21^{1 t}$ Century. Ostrava: University of Ostrava. str. 43-48.

Giddens, A. (2006). Sociology: $5^{\text {th }}$ Edition. Cambridge: Polity Press.

Grossbard-Shechtman, S. A. (2003). Marriage and the Economy. Theory and Evidence from Advanced Industrial Societies. Cambridge: Cambridge University Press.

Hromadžić, H. (2008). Konzumerizam. Potreba, životni stil, ideologija. Zagreb: Naklada Jesenski i Turk.

Lipovetsky, G. (2008). Paradoksalna sreća. Ogled o hiperpotrošačcom društvu. Zagreb: Biblioteka Antibarbarus.

Marati, J. (2012). Behind the label: The diamond engagement ring industry. URL: http:// ecosalon.com/behind-the-label-the-diamond-engagement-ring-industry/ (siječanj 2015.)

Marx, E. i Engels, F. (1978). Njemačka ideologija. U: A. Dragičević, V. Mikecin i M. Nikić (ur.), Glavni radovi Marxa i Engelsa. Zagreb: Svjetlost, Biblioteka Veliki mislioci. str. 299-343.

Matt, S. J. (2003). Keeping Up with the Joneses: Envy in American Consumer Culture, 1890-1930. Philadelphia: University of Pennsylvania Press.

McNair, B. (2004). Striptiz kultura. Seks, mediji i demokratizacija žudnje. Zagreb: Naklada Jesenski i Turk.

Merriam-Webster (2014). Strategy. URL: http://www.merriam-webster.com/dictionary/ strategy (prosinac 2014.)

Montemurro, B. (2008). Brides, Inc.: American Weddings and the Business of Tradition. URL: http://muse.jhu.edu/journals/jsh/summary/v041/41.4.montemurro.html (prosinac 2014.)

Morgan, L. H. (1877). Ancient Society or Researches in the Lines of Human Progress from Savagery through Barbarism to Civilization. Chicago: Charles H. Kerr \& Company.

Norčič, O. (1996). Šestdeset let Keynesove «Splošne teorijes. U: N. Borak, O. Norčič i D. Savin (ur.), Aktualnost J. M. Keynesa. Ljubljana: Sophia. str. 9-21.

Peračković, K. (2008). Društvo i (ili) tržište - sociološka konceptualizacija procesa marketizacije društva. Društvena istraživanja, 17(6):975-997.

Peračković, K. (2013). Osnovni pojmovi u sociologiji potrošnje. U: S. Čolić (ur.), Potrošačka kultura i konzumerizam. Zagreb: Institut društvenih znanosti Ivo Pilar. str. $25-46$.

Platon. (1970). Ijon; Gozba; Fedar. Beograd: Filozofska Biblioteka. 
Press Trust of India (2011). India fourth most dangerous place for women: survey. URL: http://www.ndtv.com/article/india/india-fourth-most-dangerous-place-for-women-survey-112349 (siječanj 2015.)

Rettner, R. (2013). More Couples Living Together Outside of Marriage. URL: http:// www.livescience.com/28420-cohabiting-marriage-cdc-report.html (siječanj 2015.)

Rhodes, C. (1994). Writing up the New Negro: The Construction of Consumer Desire in the Twenties. Journal of American Studies, 28(2):191-207.

Rifkin, J. (2005). Doba pristupa: nova kultura hiperkapitalizma u kojoj je cijeli život iskustvo za koje se plaća. Zagreb: Alt F4 - Bulaja naklada.

Schwartz, R. (1999). The Romantic Era. URL: https:/www.mtholyoke.edu/courses/ rschwart/hist255/jkr/romanticism.html (siječanj 2015.)

Scott, J. (2006). Family and Gender Roles: How Attitudes Are Changing. Cambridge: University of Cambridge.

Slater, D. (1997). Consumer Culture \& Modernity. Cambridge: Polity Press.

Stearns, P. (2001). Consumerism in World History - The Global Transformation of Desire. London: Routledge.

The Week Staff(2012). How marriage has changed overcenturies. URL: http://theweek.com/ article/index/228541/how-marriage-has-changed-over-centuries\#axzz35BT9VXaL (siječanj 2015.) 


\title{
MARITAL UNION WITHIN THE IDEOLOGY OF CAPITALIST COMMODIFICATION AND CONSUMERISM
}

\author{
Hajrudin Hromadžić and Katarina Damčević
}

\section{Summary}

This paper examines the concept of marital union as an economic and market-regulated entity, a product of the advanced processes of contemporary capitalist commodification. Familiar notions such as the institution of family, the myth of eternal love, soulmates, and the idea of engagement are understood as contextually tied to consumerist ideology, society and culture. The main argument is that economic value became integral to the internal structure and organization of marital union throughout its history, and that this has been especially evident over the last century of increased dynamics of capitalist development.

Key words: marriage, family, capitalist commodification, consumerist ideology

\section{DIE EHEGEMEINSCHAFT UNTER BEDINGUNGEN DER KAPITALISTISCHEN KOMMODIFIZIERUNG UND DER IDEOLOGIE DES KONSUMERISMUS}

Hajrudin Hromadžić und Katarina Damčević

\section{Zusammenfassung}

In der vorliegenden Arbeit wird versucht, auf das Problem der zeitgenössischen Ehegemeinschaft hinzuweisen, als eine durch Wirtschaft und Markt regulierte Entität und eine der Resultanten der fortgeschrittenen kapitalistischen Kommodifizierungsprozesse der Gegenwart, was indirekt die Behandlung der nahen Phänomene einschließt wie z. B. der Institution der Familie, des Mythos der ewigen romantischen Liebe, der verwandten Seelen und der Verlobung, die man kontextuell mit den Fragen der Ideologie des Konsumerismus, der Konsumgesellschaft und-kultur verbindet. Wir befürworten die These, dass die ökonomische Variable des Wertes der inneren Struktur der Ehegemeinschaft während ihrer ganzen Geschichte inhärent ist, was besonders mit der fortgeschrittenen Dynamik der kapitalistischen Prozesse in den letzten ein paar hundert Jahren evident wird.

Schlüsselwörter: Ehe, Familie, kapitalistische Kommodifizierung, Ideologie des Konsumerismus 
